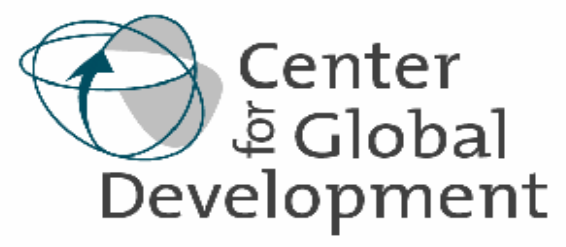

Working Paper Number 49 November 2004

\title{
Underfunded Regionalism in the Developing World
}

By Nancy Birdsall

Abstract
This paper argues that regional public goods in developing countries are under-
funded despite their potentially high rates of return compared to traditional country-
focused investments. Regional public goods only receive about 2.0-3.5 percent out of
total ODA annually according to the definition used in this paper.
The rate of return to regional investments is likely to be high, especially in Africa,
where investments in regional infrastructure and institutional integration would
reduce the high costs imposed by the region's many small economies and many
borders.
There are several reasons for the under-funding of regional public goods. First, to
produce regional infrastructure and manage multi-country institutions requires
coordination among two or more developing country governments. The recent donor
emphasis on countries' "ownership" of their own priorities is more supportive of
national programs. Second, bilateral donors prefer country-based transfers given
their potential for providing geo-strategic and political benefits, and the multilateral
banks have limited scope for lending for regional programs since their principal
instrument is a loan to a single-country government that must guarantee its
repayment. Countries could coordinate their borrowing, but that would require
reaching agreement on attribution of the associated benefits to allow appropriate
allocation of the burden of financing among two or more governments. Combined,
these problems of coordination, (lack of) ownership, and attribution make financing
of regional programs costlier for donors to arrange, and riskier in terms of their
sustainability and benefits.
In Africa the under-funding of regional public goods is primarily a political and
institutional challenge to be met by the countries in this region. But the donor
community ought to consider the opportunity cost - for development progress itself,
in Africa and elsewhere - of its relative neglect, and explore changes in the aid
architecture that would encourage more attention to regional goods.




\section{Underfunded Regionalism in the Developing World Nancy Birdsall* \\ October 23, 2004}

(forthcoming in The New Public Finance: Responding to Global Challenges. Kaul et al. (Eds.). New York: Oxford University Press.)

The economy of all of sub-Saharan Africa is about 10 percent smaller than that of Chicago. ${ }^{1}$ Imagine if Chicago had more than 40 school superintendents, customs bureaucracies, army chiefs of staff, public works ministries, and central banks. Imagine that each of Chicago's neighborhoods also had its own set of tariffs and non-tariff barriers. Imagine that people who lived in one neighborhood in Chicago could not necessarily travel to other neighborhoods.

The world's developing regions would benefit from greater integration of their economies. I argue in this paper that the institutions and infrastructure for greater integration have been inadequately funded, given their potential returns.

In the last decade there has been new attention to international or global public goods - such as the protection of biodiversity and the improved management of global financial flows - that would, were they better funded, have development benefits while addressing global challenges with benefits to developed countries as well. ${ }^{2}$ Still relatively neglected, however, are regional and transnational or multi-country public and quasi-public goods. In this category are cross-border physical infrastructure (roads, dams, gas pipelines, power grids) and cross-border multi-country measures to manage shared watersheds, forests and other natural resources. Also in the category of regional public goods are the regional and sub-regional institutions meant to address regional issues or develop regional goods, such as regional trade agreements, regional monetary unions, regional stock markets, and the regional and sub-regional United Nations agencies (such as the Economic Commission for Africa) and the regional development banks themselves.

In this paper I argue that regional public and quasi-public goods are probably undersupplied and "underfunded" - in the sense that in the developing world there are many potential cross-border and other regional investments that are not being financed,

\footnotetext{
*President, Center for Global Development. I am grateful to Alan Gelb, Bill Cline, Steve Radelet and Todd Moss for guidance and for comments on earlier version, and to Gunilla Pettersson and Sandip Sukhtankar for excellent help on the difficult task of finding, assessing and organizing the limited data. ${ }^{1}$ Other comparisons are included in the text below, and shown in Table 3.

2 The Global Environment Facility is an example of an initiative meant to finance such global goods as preserving biodiversity and minimizing emissions of greenhouse gases. It does so by encouraging developing countries to take on these tasks by subsidizing the costs of implementation. Programs to support tropical agricultural research similarly support a global "good"; in that case the development benefits to particular countries where new seed varieties have raised production and incomes are more obvious.
} 
but which would yield higher returns than other development investments. The argument of probable underfunding begins with that applied to public goods in general. The undersupply of regional public goods reflects the difficulty of dealing with regional externalities, which arise when "goods" or "bads" of one country spill over bringing costs or benefits to neighbors in the same "region" that are at least in part non rivalrous (consumption by one country does not diminish consumption by another) and not excludable, or when they are excludable (as in the case of say a transnational road) but cannot be easily priced. ${ }^{3}$ That general problem is complicated in the developing world, especially where donor financing of investments is considerable, by two additional problems of coordination and attribution.

First, to produce regional infrastructure and goods and services and to manage multi-country institutions requires coordination among two or more governments. That is a tall order in the developing world, where the institutions of government are often poorly financed and staffed. In addition, the production and financing of regional goods requires attribution of benefits and thus the appropriate allocation of the burden of financing the initial costs of the investment. This matters to the extent that developing countries rely on concessional and other credits from official bilateral and multilateral institutions such as the World Bank (which must be contracted to individual governments), or on grant funds that are allocated on the basis of individual country performance and poverty levels. Even in the case of shared roads the appropriate attribution of costs and benefits may not be obvious. In the case of watersheds, airport hubs and power grids (all of which are quasi-public goods, as they are not completely non-rivalrous), attribution of benefits and thus costs is even more difficult. ${ }^{4}$

Regional goods that benefit only developing countries are likely to be underfunded compared to global goods, since the latter provide benefits to donor countries (diffuse as they might be) so that donors have an interest in financing their production. Taxpayers in the rich world are more likely to be interested in helping China and Brazil minimize greenhouse gas emissions than in halting the spread of Chagas disease, or supporting a regional currency union in Africa or South Asia.

I begin with a brief discussion of the concept of regional public goods, their relevance for broad development goals, and their relative neglect given the current institutional aid architecture (section 1). I note that despite the potential high returns to financing for regional projects and programs, donor financing is minimal (section 2). I

\footnotetext{
${ }^{3}$ There are also non-neighbor but also non-global externalities - such as the exposure to financial volatility of all emerging market economies, or to commodity price shocks of all oil producers - which I do not treat here. Cross-border externalities, such as exposure to air pollution, or to the benefits of a common watershed or a transnational road, are one kind of regional externality that is shared by true neighbors with a common border.

${ }^{4}$ Even in the case of regional institutions (which might, for example, represent a multi-country group in trade negotiations), a country that does not contribute adequately to the cost of creating and maintaining an institution cannot be easily excluded from the resulting benefit. Most regional goods are actually "quasipublic" goods. The benefits of a pure public good such as national defense are not diminished by sharing, and exclusion is impossible. Neither is the case with cross-border infrastructure or watershed management, for example.
} 
then discuss evidence (section 3) suggestive of what could be high economic returns to "regional" investments in multi-country infrastructure and institutions in sub-Saharan Africa, a region receiving special attention from donors because of its failure to grow in per capita terms in the last several decades, and because so many of its countries seem unlikely to achieve the Millennium Development Goals. ${ }^{5}$ I turn then to a discussion of the additional constraints to the financing of regional public goods compared to country programs (section 4). Despite the official donor community's mounting concern with poor development progress in Africa, limited attention and financing to regional goods is not all that surprising. I conclude with some implications for future development assistance.

$\underline{\text { Section 1. Regional public goods and the international aid architecture }}$

Regional public goods should in principle be attractive to the development community. They can be thought of in two categories: those that benefit a particular region (such as infrastructure) and those that are stepping stones towards or a building block of global public goods, such as regional trade agreements that are consistent with and would feed into a multilateral trade regime. ${ }^{6}$ Assuming the returns to regional investments are as high or higher than the returns to conventional country-based assistance, both types ought to be attractive not only to their regional participants but to donors concerned both with ensuring aid is effective and with managing such global public goods (and "bads”) as global warming, infectious disease, and international crime and terrorism.

Funding of regional goods seems to have been limited by the lack of any compelling evidence of relative costs and benefits of different kinds of development spending (at any level), combined with the absence of any particular donor entity that would be the champion of regionalism. Consider first the lack of evidence on relative returns. Among donors and creditors, the early logic of estimating ex ante rates of return for infrastructure projects (taking into account shadow prices and so on) had yielded by the 1980s to a less technical and more practical calculus, as financing for social programs (with less easily quantified benefits) became acceptable ${ }^{7}$, and as it became clear that the returns to investments varied greatly across countries depending on policies and institutional arrangements. In the last decade, the donor community has begun to provide budget support, ceding whatever control they had over specific investments and sectoral

\footnotetext{
${ }^{5}$ The MDGs are internationally agreed goals to reduce poverty, infant mortality, the spread of certain diseases and so forth, by definable amounts, by 2015. See http://www.un.org/millenniumgoals. For analysis of the prospects of achieving the goals, see Clemens, 2004; and Clemens, Kenny and Moss, 2004.

${ }^{6}$ Both types are described and discussed in Birdsall and Rojas-Suarez (2004).

${ }^{7}$ Almost all government and donor investments go to some sort of "public goods" such as education, rural roads, or strengthening of property rights. For all these, it is difficult to do any credible cost-benefit analysis because of the difficulty of measuring positive and negative externalities. The issue is well-known in the case of education for example, for which private but not public returns to investments can be calculated. As a result there has long been debate about the right proportion of investment in, for example, primary vs. higher education. The unmeasured benefits of each associated with such externalities as the effects of primary education on mothers' and children's health and the effects of higher education on effective nation building, makes comparison of their relative social returns impossible (Birdsall, 1996).
} 
allocations (and even that was sometimes limited since traditional aid transfers are also to some extent fungible) to country officials. The implicit recognition on the part of donors is that within countries differing priorities about public spending across sectors have to be resolved through the political system, and that only if the resulting priorities are "owned" locally will the spending on them be sustained and effective. ${ }^{8}$

What is difficult to compare within countries is more difficult with respect to decisions on the allocation of scarce donor funds among global public goods, regional programs and country programs. In the case of global public goods and "bads" such as biodiversity and greenhouse gas emissions, increased interest and attention to them in the last two decades, originally inspired by the environmental movement, has no doubt been behind the apparent increase in their share of total annual development assistance (now as high as 10-16 percent, depending on how they are measured). ${ }^{9}$ Though there has been some sense that donor financing of global public goods should not reduce the amounts available for conventional country assistance, ${ }^{10}$ in the 1990 s when the share of development assistance for global public goods was rising, total development assistance was not. So it is likely that donor financing of global public goods has not been fully "additional" (though there is no way to be sure the additional spending would in fact have been available for conventional country programs). ${ }^{11}$

Without compelling evidence on relative returns, there is also no consensus on the "right” allocation of limited donor resources for regional public goods. Certainly any increase in spending on regional infrastructure and regional institutions could end up reducing spending at the country (or global) level. So regional goods are likely to be underfunded because of institutional constraints (as is the case with global public goods, though less so) rather than on the basis of any (virtually impossible) comparison of relative costs and benefits of single-country investment projects versus regional investment projects.

It does not help that donors have not historically been organized to initiate or even consider financing of multi-country programs. Prior to the end of the Cold War, a goodly chunk of donors transfers was motivated largely by geopolitical and strategic concerns, and to some extent by commercial ties established during the colonial period. That obviously implied government-to-government transfers. In addition, there is no obvious

\footnotetext{
${ }^{8}$ I was unable to obtain information on rates of return to multi-country infrastructure or other "regional" projects from the World Bank. They are available for a few cases such as the Chad-Cameroon pipeline project, but even in this case the expected rates for return are reported separately for what are two separate loans to the two countries.

${ }^{9}$ See Appendix Table 1. Prior to the 1980s, donors did finance agricultural research and some research on tropical diseases. It was only in the late 1980s that donors established programs to support developing countries in combating emissions of greenhouse gas emissions and ozone-depleting substances, preserving biodiversity and so on. For a critical exploration of the issue of global public goods in relation to development in the development literature see for example, Kaul, Grunberg and Stern, eds. (1999); Kanbur, Sandler and Morrison (1999).

${ }^{10}$ Kaul, Conceicao, Le Goulven, and Mendoza, eds. (2003).

${ }^{11}$ Analysis by Reisen et al. also leads to the conclusion that there has been some but not total additionality. They report an "offset coefficient" of 25 percent to traditional aid when funding rises for global public goods, using an extremely broad definition of GPGs used in the OECD Creditor Reporting System - which I discuss briefly below.
} 
"right" institutional arrangement that would create accountability for the financing and implementation of regional programs. The example of global public goods illustrates this point. For global public goods, the framework and the financing would seem to be logically assigned to such global institutions as the United Nations and its various agencies and the World Bank. Thus the World Health Organization is the channel for managing and financing worldwide control of such diseases as SARS. However, to the extent the implementation of relevant programs (such as pollution control) is managed by individual governments, the subsidiarity principle would imply that a recipient government could receive external financing from any bilateral or multilateral donor to do the implementation. ${ }^{12}$ As a result many donors and agencies end up providing some financing and supporting some management within countries of programs in support of global goods.

Complicating further the situation, the main instrument of the World Bank, a global institution, is a loan to a single recipient government which must "guarantee" its repayment, and as a result its history and culture reflect its longstanding experience in supporting country-based programs. Only recently has this begun to change, with the (new) use of its soft window (loans from which in principle do not need such a guarantee) and its limited grant facility, for global and regional programs. For much the same reason, the regional development banks have concentrated almost exclusively until relatively recently on country-based loans and programs, despite their roots in a "regional" mission. This is the case even for the Inter-American Development Bank (IDB), which among the multilaterals has long made fostering regional integration a high priority. $^{13}$ (In late 2004, the IDB Board approved a new program of grant financing for regional programs, but only in the amount of $\$ 10$ million per year, compared to annual new country lending commitments on the order of $\$ 6$ billion a year.)

As with global public goods, it is not entirely clear that any one agency would be most effective and efficient in financing and supporting regional investments, since implementation may take place at the country level or in a "regional" institution or both. An assignment of "regional" to a specific institution (or "donor") might fill the gap in the perusal of high-return investment opportunities. But it would not alone address the tradeoff between economies of scope (that the agencies managing country programs have the technical expertise and the systems to permit low-cost diversification to regional project support) and the subsidiarity principle (that the agency closest to the relevant level should manage it).

This issue for the donor community - of the intersection of the international aid architecture with the unrealized potential for regional and global programs -- has been discussed carefully and extensively elsewhere. ${ }^{14}$ I raise it here mainly to note that there is no clear mandate and accountability combined with adequate financing in any donor-

\footnotetext{
12 Sagasti and Bezanson (2001) are cited by Reisen et al. (2004) on this point.

13 The IBD reports disbursements of ordinary capital of $\$ 1.98$ billion to regional programs and projects over the period 1961-2002, compared to total commitments over the four decades of about $\$ 2.5$ billion, Inter-American Development Bank (2003).

${ }^{14}$ E.g. Kanbur (2001).
} 
based institution to address regional needs. What might be called the international aid architecture is simply not conducive to funding of regional goods.

Section 2. Existing donor commitments to regional programs and projects are small

For decades the principal recipients of official development assistance have been individual countries in the developing world. Of the estimated $\$ 61.5$ billion in development aid disbursed in 2002, ${ }^{15}$ I conclude below that something on the order of 2.0-3.5 percent (or about $\$ 2$ billion) is spent annually on multi-country programs and projects in the developing world that are not "global" public goods (such as tropical agricultural research) but benefit two or more countries that are geographically related (such as harmonization of stock markets in Africa, development of a shared electricity grid in Central America, or management of a shared watershed). ${ }^{16}$ The rest was channeled through agreements with national governments of individual countries in what might be called conventional country-focused assistance. ${ }^{17}$ Not only is most bilateral aid channeled through recipient countries, but most multilateral aid as well. ${ }^{18}$

There is no simple way to estimate donor financing of regional projects and programs, because the existing sources of information on commitments by donors to financing of regional goods use widely differing definitions. The OECD publishes estimates based on donors' reports of the sectoral allocation of their annual commitments. The donors agreed on the "sectors" for which their commitments would be classified as regional public goods or global public goods or neither. The choice of sectors reflects a willingness to overstate rather than understate support for regional (and global) programs, essentially because of a decision to capture any support which might have any spillover benefits to neighboring countries. For example support for "waste management", "road transport" and "education/training” are classified as regional public goods, even when all the support went to a single country. ${ }^{19}$

\footnotetext{
${ }^{15}$ OECD (2004).

16 This estimate is based on a definition of commitments to regional programs by donors set out below; official estimates of the Development Assistance Committee of the OECD are much higher because they use a much broader definition that includes single-country commitments with any potential spillover benefits for neighbors.

${ }^{17}$ A notable exception from the past would be the Marshall Plan, in which the United States insisted that the Europeans work out the allocation of U.S. transfers across recipient countries before making any transfers to any single country. The CGIAR (Consultative Group on International Agricultural Research) is one current example of a program in which spending is not channeled through individual recipient countries.

${ }^{18}$ Some private transfers, such as those of the Rockefeller and Gates Foundations for development do finance regional and global public good (as opposed to country programs). Most private transfers from individuals and foundations go to private recipients (charitable organization, educational institutions, families).

${ }^{19}$ I refer to the OECD Creditor Reporting System (2004), explained and used by Reisen et al. (2004). Similarly to the case of regional goods, support for "human rights" work, "infectious disease control", "economic policy", "financial policy" and "monetary institutions” are all classified as GPGs, even if the support went entirely to one country.
} 
Using these official donor-defined data leads to the conclusion that regional public goods constituted about 15 percent of all overseas development assistance in the period 1997-2001 (and GPGs another 16 percent). Including a more limited set of sectors in the definition of regional public goods, (air transport, river development, rail transport, protection and pest control, flood prevention/control, water resources protection, and "support to national/regional NGOs") - though still very much guessing about whether support went to more than one country - reduces the percentage to about 6 percent in 1997, and to less than 3 percent in 2002 (Table 1).

A third alternative is to sum up disbursements to regional projects shown in the annual reports and other publications of the various agencies and institutions, which appear in their own reports to define "regional programs and projects" as those in which more than one recipient country is legally engaged as a beneficiary, either in the context of that specific project under a project-specific arrangement, such as the Great Mekong Sub-Region project in South Asia or the Puebla-Panama project involving Mexico and several countries of Central America, or as a member of a regional institution in which all other members are also aid recipients such as Nepad, the New Partnership for African Development. $^{20}$ In addition it might make sense to add bilateral donor contributions to the soft windows of the regional development banks - since they are themselves "regional” institutions -- although this inflates spending on regional programs and projects strictly defined since the RDBs as shown in Table 2 spend little (0.4-2.7 percent) of their resources on the latter. Those contributions to the African, Asian and InterAmerican Development Banks amounted to another $\$ 1.3$ billion in $2002{ }^{21}$ Adding the total of $\$ 788$ million in Table 2 and the additional $\$ 1.3$ billion that bilateral donors contributed to the soft windows of the regional development banks still keeps the total proportion of donor financing for regional programs in 2002 at about \$2 billion out of total donor spending of approximately $\$ 60$ billion in that year.

Table 1 summarizes the results using the three different definitions of regional programs and projects. The bottom line is that just 2.5-3.5 percent of all donors spending goes to regional programs, using a definition based on more than one country being legally involved as a beneficiary (as opposed to benefiting indirectly from the "spillover" of say better financial management in a neighbor).

Finally, note that these data are not easily available in any form that could be considered comparable across institutions and years. All of the multilateral banks support the idea of better integration within regions and recognize the need for cross-border

\footnotetext{
${ }^{20}$ Still, another approach would be to compile the annual disbursements of all creditors and donors to regional projects, but it is difficult to make a complete list of such projects and their financing (but see Appendix Table 2 for a list of selected regional World Bank projects from its project database, http://web.worldbank.org/WBSITE/EXTERNAL/PROJECTS/0,,menuPK:235787 pagePK:64020917 piP K:64021009 theSitePK:40941,00.html).

${ }^{21}$ The donors also have capital paid in to back the hard windows of those banks, but these amounts are a stock not an annual flow, and as discussed below, the hard windows finance loans which are not conducive to financing regional programs.
} 
infrastructure and other projects. ${ }^{22}$ They all periodically prepare and publish strategies for supporting regional integration. However, though they generally publish information on specific "projects" that are considered regional in nature, they have not agreed on any definition of what is regional among themselves, and as is obvious from the description above, do not systematically define and publish the portion of their spending that is "regional" vs. "country-based". ${ }^{23}$ This reflects the banks' longstanding focus on country programs, associated with their principal instrument, the loan to a single government.

In the case of the bilaterals, the situation is worse. Except for an "unspecified" category that includes regional along with other programs, there is no information on transfers that are not specific to a particular recipient country. The numbers in Table 2 for the UK and U.S. probably exaggerate regional lending since they include figures for all "unspecified" funds going to a region, and are likely to include funds that in fact went to individual countries.

Section 3. Lost opportunities: The potential high returns to regional institutions and investments in sub-Saharan Africa

Sub-Saharan Africa is the poorest and in other respects the least developed of the large regional groupings, measured using any number of regional averages of economic indicators. Of 31 "top priority" countries where, according to the UN urgent action is needed to meet the Millennium Development Goals, 25 are in sub-Saharan Africa. ${ }^{24}$ For more than a decade it has been by far the largest recipient of aid on a per capita basis and in terms of its own GDP.

The region has characteristics that make the potential returns to investing in regional goods very high and thus ought to make financing of regional programs and projects by donors a priority. For example, an estimated 28 percent of the multi-country highway in the ECOWAS (Economic Community of West African States) countries are estimated to be dysfunctional (called "missing links") according to the United Nations Economic Commission for Africa. Estimated "missing links" in other regional groupings of Africa range from 14 to 47 percent. $^{25}$ Donors' willingness to finance regional projects (or lack of interest) are likely to matter to the overall allocation of investment resources given that donors finance as much as 50 percent of government budgets in some countries, and an even higher percent of public investment. ${ }^{26}$

\footnotetext{
${ }^{22}$ See for example the African Development Bank (2000); Agarwala and Prakash (2002); and InterAmerican Development Bank (2003). In the 2004 World Bank report Strategic Framework for Assistance to Africa, p. 66, it is noted that the bank is highly constrained in its support of regional programs in its hard window, but that "Change in IDA policy is imperative here and efforts are underway to realize this."

${ }_{23}$ The Africa region of the World Bank is currently developing aggregated data on "regional" projects.

${ }^{24}$ UNDP (2003), p. 44.

${ }^{25}$ UNECA (2004), chapter 7.

${ }^{26}$ In 1999 donors financed 50 percent or more of central government expenditure in such countries as Madagascar; Senegal; Sierra Leone; and Uganda (WDI, 2004). They supply 40 percent of more public resources in at least 30 developing countries, for example, Tanzania; Bolivia; and Nepal (World Bank, 2004). Since most donor financing is for investment, not operational or recurrent spending, it is clear that donors in countries relying heavily on aid are financing the majority of public investment.
} 
The relevant characteristics are most easily described under two related categories: economies that are small without much potential for complementary trade; and economies with many borders, the costs of which are relatively high.

Small economies. Market size affects the potential for specialization and the ability of investors to achieve the economies of scale that are critical to be competitive in global markets. Sub-Saharan Africa's economy as a whole is large enough (about the size of the economy of Belgium) to support some specialization and scale investments were it fully integrated into a single market. But the region's "internal" market is in fact highly divided among 48 countries, and many are very small indeed. Malawi's economy is $1 / 100^{\text {th }}$ the size of Denmark's (4/100ths in PPP terms). ${ }^{27}$ Even the largest economies South Africa, Nigeria, and Sudan - are relatively small. South Africa's economy is less than one-third the size of Ohio's (and the Netherland's) economy (Table 3).

The small size of the "domestic" (regional) market in sub-Saharan Africa inhibits investments in manufacturing and services that require minimum scale to be efficient and competitive. With most countries confined to producing primary goods and so without much value-added or specialization, there is in turn little scope for intra-regional trade. Trade within Africa is an estimated 7.8 percent of all the region's trade, compared to 17 and 48 percent for Latin America and Asia respectively (Table 4). Only South Africa is somewhat of an exception, with 16 percent of its exports going to the region. ${ }^{28}$ The lack of much intra-regional trade reflects and reinforces the lack of specialization and resulting lack of complementary demand across countries (Yeats, 1998). More than 70 percent of Africa's exports are primary products (compared to 40 and 13 percent for Latin America and Asia).

Many and costly borders. Borders inhibit trade. McCallum (1995) presented startling evidence that 1988 merchandise trade flows among Canadian provinces were 20 times greater than those between Canadian provinces and U.S. states, despite the relatively porous Canadian-U.S. border. ${ }^{29}$ Later studies (Wei, 1996) led to lower estimates of the difference, but not to a change in the conclusion that even highly porous borders between countries with a common language create costs, presumably because of differences in regulations, building and other standards, customs, tastes, as well as in the case of Canada, obvious border barriers such as pre-NAFTA tariffs.

Sub-Saharan Africa copes with higher border costs than any other region, particularly when the offsetting benefits of larger coast-to-land ratios and greater inland river access of other regions are taken into account. It has an estimated 134,000 kilometers of national borders, of which more than 50 percent are non-coastal; ${ }^{30}$ Europe has more borders overall (almost 200,000 kilometers), but fewer than 10 percent are non-

\footnotetext{
${ }^{27}$ World Bank (2003).

${ }^{28}$ International Monetary Fund, Direction of Trade Statistics.

${ }^{29}$ See also Helliwell (1997) and Anderson and van Wincoop, 2001. Spolaore and Wacziarg (2002), using OECD country data, show that whenever scale effects are present, political borders affect steady-state per capita income levels and growth rates.

${ }^{30}$ These numbers have not, to my knowledge, been estimated before. Sandip Sukhtankar made clever use of available information to prepare the necessary program that is available from the author and him.
} 
coastal. Western Europe has much greater penetration of navigable rivers, as do England (a point Adam Smith made to explain England's domination of world trade into the $20^{\text {th }}$ century) and the United States. Estimated transit costs, including transportation and insurance payments are as high as 56 percent of the value of exports for Malawi, 36 percent for Uganda, and at or above 25 percent for eight other countries out of a total of 14 countries. $^{31}$

Trade liberalization has reduced unweighted average tariff rates in sub-Saharan Africa in the last 20 years, from about 35 percent in 1980-1983 to as low as 15 percent in 2000-2001. ${ }^{32}$ That is not particularly high, certainly not compared to other developing regions, and may anyway reflect in part the continued reliance of some countries on the revenue tariffs generate. It is other barriers that are more problematic, and unfortunately are more difficult to reduce. Fixing problems at the border such as customs bribery and bureaucracy and legal and regulatory differences across markets, requires institutionally demanding reforms within countries and complex harmonization between countries. Reducing the high costs of cross-border transport requires major new investments that are not likely to attract private finance and cannot be afforded by governments.

Africa is probably the continent with the least-cost hydroelectric energy sources in the world. ${ }^{33}$ But without shared electricity grids, spending on power is high, keeping local industries less competitive than they could be. The opportunity cost of the lost network externalities in sea and air transport, because of the political difficulty of arranging efficient hubs (with which some countries would lose and require compensating transfers), is also high. ${ }^{34}$

Costly borders and the related small size of its economies compound sub-Saharan Africa's inherent geographic disadvantages, including the large land mass with limited access to the sea (compared for example to England) and to rivers (such as the U.S. has with the Mississippi, Europe with the Rhine and the Danube); and the high disease burden associated with tropical climates. Radelet and Sachs (1998) show the relevance of these initial disadvantages for country-specific shipping costs; and the relevance of high shipping costs for success in manufactured exports and in economic growth. ${ }^{35}$

The economic disadvantage of Africa's many and costly borders, and many and poorly integrated small economies, can be overcome. Some of the same points could be made for the various economies of Central and South America; for Nepal and Mongolia

\footnotetext{
${ }^{31}$ Estimates are available in UNECA (2004), Table 7.3. According to UNECA "the high costs are due to noncompliance and incomplete implementation of bilateral and multilateral agreements,” p. 141.

${ }^{32}$ UNCTAD (2004). UNCTAD reports that the weighted average tariff rate in sub-Saharan Africa decreased from 26 percent in 1980-1983 to 11 percent in 2000-2001. The decline in the unweighted average tariff rates from the period $1997-1999$ to 2000-2001 was 4.2 percentage points.

${ }^{33}$ Hydropower from the Inga in the Democratic Republic of the Congo could supply the growing electricity needs of all of southern Africa for the next seven years at 2 cents per kilowatt hour, according to World Bank staff (personal correspondence, 2003).

${ }^{34}$ Alan Gelb, the World Bank chief economist for Africa, made these and other points to me.

35 They measure shipping costs using information on FOB (free on board) vs. CIF (cost-insurance-freight) costs of imports.
} 
were they to be economically more linked to China, and so forth. But Africa is the region that best illustrates the high cost of political borders, especially for small and landlocked economies. Its situation suggests the potentially high returns in many parts of the developing world to any policy adjustments and any new investment - in cross-border, multi-country infrastructure, and in institutional integration - that would reduce the cost of borders. ${ }^{36}$ Because almost all developing country economies are smaller than any developed country economy (with notable exceptions such as India and China), regionalism ought to be more prominent on the development agenda.

\section{Section 4. Coordination, ownership, attribution and underfunding}

If, as the situation in sub-Saharan Africa suggests, the returns to regional investments could be high, why haven't donors encouraged and supported such investments? The tendency for public goods in general to be underfunded ${ }^{37}$ is complicated by at least three problems that arise in the context of donor financing.

First there is the coordination problem. To produce regional infrastructure and goods and services and to manage multi-country institutions requires coordination among two or more governments. That in itself is a tall order, particularly in the developing world, where the institutions of government are often poorly financed and staffed. Ironically, recent donor reforms which focus on fostering and respecting "ownership" by developing countries of the programs supported, do not help. Ownership by recipient countries is more difficult to achieve when more than one country is involved, and probably multiplies rapidly as more than two are involved. To some extent, this is still the case, but to a lesser degree. Since the end of the Cold War, the donor community has become more focused on and more transparent about the need to ensure that aid goes to countries where it is most likely to be effective in fostering growth and reducing poverty. The rhetoric and new commitments made at the international conference on financing for development at Monterrey; the attention to peer review and to tracking progress toward achievement of the Millennium Development Goals in the Development Assistance Committee (of the OECD); and the increasing consensus around a comprehensive, country-driven approach with considerable ownership by recipient countries, are all evidence of that. ${ }^{38}$

36 This is all the more true since many pressing development problems, in the case of Africa including AIDS and conflict, are basically transnational, and require multi-county efforts to resolve them.

${ }^{37}$ Regional programs that are pure and quasi-public goods are likely to be undersupplied and underfunded (compared to some unknown optimum) by developing country governments for the same fundamental reason as other public goods: given that any one producer (country) cannot capture all the benefits, all will hope to free-ride.

38 The U.S., the largest donor in absolute terms, has been less attuned to the efforts of the donor community to increase coordination among themselves and reduce the bureaucratic and other burdens on recipient countries associated with multiple programs and procedures. But the Untied States has implicitly bought into the need for recipient country ownership of aid-financed programs. The U.S.'s new Millennium Challenge Account and its new financing to fight the AIDS pandemic both put emphasis on selecting recipient countries that have demonstrated they will use additional resources effectively, and on administering the new resources in a manner that puts initiative and management in the hands of the recipient countries. See Radelet (2002). 
But these donor reforms are not likely to encourage any new emphasis on regional programs. The focus on ownership and greater harmonization does not address the immense difficulties aid recipient countries face in cooperating among themselves, and the resulting limits to their effective demand for financing of regional programs. To the extent donors respond to the explicit interests of recipient governments, donors are less likely to focus on financing of multi-country programs. ${ }^{39}$

Then there is the problem of attribution of the benefits and thus the burden of the costs of financing and managing an investment when more than one recipient government is involved. For regional activities involving self-financing by participating countries, attribution of the costs is part of the coordination challenge. For countries relying on donor funds, and for their donors, attribution creates an additional barrier to negotiating and managing an investment. In the case of the multilateral banks, the attribution issue has in effect made lending to the middle-income countries for regional programs much more difficult than lending for country programs, since ex ante the borrowers must agree among themselves on their respective debt obligations. The limited availability of grant funds in the banks has reduced any incentive they might have had to encourage the development of regional projects and programs for their financing. (Indeed it is notable that despite this they have all recently developed strategies to support regional programs, and each seems to have increased its support for such programs in the last decade though as noted above the lack of comparable data over time makes it difficult to demonstrate this.) ${ }^{40}$

The advantage of grant financing is that it eliminates some of the problems of coordination and attribution among recipients. Compared to loan financing grants also give the donor more implicit control over design, timing, environmental safeguards (in the case of infrastructure), and in the end over the relative benefits to the individual recipient countries - reducing the constraint of strong ownership by more than one country, though at some cost if ownership matters for effectiveness.

There are only a few cases of MDBs making loan commitments to a group of countries. World Bank financing for the Chad-Cameroon pipeline took the form of two separate loans, adding to the cost of the transaction. I could find no examples of regional programs being financed by three or more separate loans; that is probably because the transactions costs go up by the square of the number of involved parties. ${ }^{41}$ MDB loans

\footnotetext{
${ }^{39}$ It is interesting that donor financing for global public goods does not require the same kind of coordination or "ownership" on the part of recipients. This is particularly the case for "weak link" public goods, such as control of infectious disease, in which the weakest link in the global chain will make the entire chain vulnerable. Rich country donors finance the Global Environment Facility to encourage protection of biodiversity in part because of their own demand for globally beneficial biodiversity; and they contribute heavily to financing of the World Health Organization and the Global Fund to Fight Aids, TB and Malaria, in part to minimize their own exposure to health risks. Regional public goods that benefit entirely or mostly countries in the developing world, such as research on semi-tropical dry land agriculture and on dengue and yellow fever, do not benefit from the same donor interest.

${ }^{40}$ The banks' concessional windows do not need the recipient governments' guarantees, and that has made financing of some regional projects of the banks possible - though they do still require an agreement between at least two recipient governments on sharing the costs of borrowing.

${ }^{41}$ And it is easier to support investment in infrastructure such as a pipeline, where the upfront costs can be allocated, than in institutional strengthening (for example of a multi-country stock market).
} 
have been mostly made from the MDBs' concessional or "soft-window" funds. These have a high grant component, and are funded from direct cash contributions of donors (for example to IDA), rather than from borrowing by the MDB on capital markets. They therefore do not require the recipient country to provide the government guarantee required for all "hard-window" loans carried on the balance sheet of MDBs. An example is the Central American power grid financed by the IDB. The IDB has also been able to make loans to sub-regional banks in Latin America without receiving a set of recipient governments' own guarantees, which would have required their allocating among themselves the amounts of their contingent liabilities, because unlike the World Bank, its own charter does not require a government guarantee from its hard window.

Within the World Bank, the country loan instrument is, reasonably enough, a fundamental reason for the organization of staff into country teams, and for the annual allocation of scarce concessional (IDA) funds across countries. With country-based allocations, country teams are loath to give up potential lending funds for non-country, regional projects.

The regional development banks could become more active in support for regional programs if their members decided they should use more of their limited concessional resources for grant funding, or were their donor members to increase their direct contributions for such programs, or were all their members, including the middleincome countries to agree to allocate more of their net income for financing regional programs via grants. The first case would reduce available funds for the poorest countries now reliant on concessional loans. The second would require donors to permit use of grant or highly concessional funds for projects that would be likely to benefit the middle-income developing countries. The last would imply higher costs of borrowing for the middle-income countries, and thus ex ante agreement on accepting higher current costs for unclear possible future benefits (were they to become beneficiaries of multicountry projects). None of these possibilities seems likely without a major reconsideration of current priorities and processes in the multilateral development banks.

Bilateral donors also face complications in developing and supporting multicountry programs. There is still the need for a single interlocutor who can be held accountable for managing a multi-country program (even if not a legal entity able to borrow). And there is the risk of a "weak link" country (in the chain of effectiveness); a major program with SADC (the Southern African Development Community) could be hurt if donors felt the need to cut off all aid to Zimbabwe, for example.

In short, the challenge of coordination among recipients makes regional financing not only costlier for donors to arrange, but riskier in terms of its sustainability and its benefits. The irony is that the difficulty of achieving the necessary coordination is a function of underdevelopment itself. That creates the logic for financing the "demand" for regional public goods (via strengthening of regional institutions) and not just their supply. 
The absence of any self-interest on the part of donors (in contrast to global public goods) and the additional costs and risks (compared with country-focused assistance), mean we can be reasonably sure that regional public goods are greatly underfunded, and that their funding has potentially higher economic returns than any other category of development financing.

\section{$\underline{\text { Conclusions and Implications }}$}

In the Africa region, agreeing on enhanced provision of regional goods that directly benefit the region is primarily a political and institutional challenge to be met by the countries of the region. The impetus is already there, as is obvious in the recent formation of the New African Partnership for Africa (Nepad), the Macroeconomic and Financial Management Institute of Eastern and Southern Africa (MEFMI), and the longstanding success of the Southern Africa Customs Union (SACU), all of which clearly have African ownership. ${ }^{42}$ The donor community also has an interest in strengthening local African regional institutions, since they are likely to form the backbone for eventual agreed financing of high-return projects in reducing poverty and managing disease and other regional burdens, and because they may constitute the setting for the region to participate in the production of global public goods. This is the case, for example, with the UN Economic Commission for Africa and the African Development Bank. There is no reason that they could not now attain the technical level and the influence of their counterparts in Asia and Latin America, given the tremendous increase in the number of highly trained Africans in the last few decades. (The donors might also consider increasing the financing of the African Development Bank for managing a much greater volume of regional infrastructure programs, using the kind of performance based measures that the United States linked to incremental financing of IDA in a recent replenishment. ${ }^{43}$ )

In the trade area, there seems little question that African policymakers would benefit from clear incentives to move quickly, even unilaterally, to reduce the high costs they now impose on themselves. The region would be immensely better off without the complications of the one dozen trade agreements that now exist, all but three of which have no more than two or three members. ${ }^{44}$ Resources to manage their customs institutions and harmonize their border arrangements trade negotiations ought to be a high priority for external financing in the context of discussion in the Doha round of trade facilitation.

The principal donor priority, however, should probably be financing of multicountry physical infrastructure. Because of both colonial investment patterns directed more at European trade and post-independence underinvestment, the cost of borders in Africa is significantly higher because the infrastructure is so weak. This is a relatively

\footnotetext{
${ }^{42}$ For a good review of another half dozen African regional institutions, including the West African Economic and Monetary Union and other currency arrangements, see USITC (2003).

43 The United States agreed to increase its contribution to IDA by $\$ 300$ million during the $13^{\text {th }}$ replenishment, subject to certain performance targets. See IDA (2002).

${ }^{44}$ Global Coalition for Africa, 2001, Tables 1 and 2.
} 
easy area for donors to get into, where the demand is clearly huge (and constrained more by lack of resources than capacity) and from which most donors (bar IDA and the EU) have largely withdrawn in favor of the social sectors.

The potential role of the multilateral development banks in the financing of regionalism is much greater than can now be realized. The banks have all defined the issue well, in regional strategy documents. Their critical constraint is the lack of an appropriate instrument that allows them to use their existing capital to finance regional programs. What financing they have done has had to come mostly from concessional lending resources and from highly limited grant resources. The bilateral donors could take leadership, especially in the regional banks, in creating new financial mechanisms that would encourage regional lending. The donors, for example, could encourage more use of net income to finance regional initiatives. Since the borrowing costs of middleincome countries would be affected, they would need to have more influence in setting priorities for use of such resources. ${ }^{45}$ Bilateral donors could also develop facilities that would finance guarantees for regional groupings that were borrowing from the MDBs or on the private market, or could subsidize the borrowing costs to individual countries participating in regional borrowings. The donor community, through the Development Assistance Committee of the OECD, should also establish common reporting requirements for all donors and creditors on their support for regional programs and projects. Some work would need to be done on concepts, definitions and measurement.

In short the donor community, particularly those most active in Africa, should almost certainly undertake careful assessments of the possibility that they are missing opportunities to support financing of major investments that would attack that region's currently prohibitive costs imposed by its borders. The institutional demands all countries face in agreeing with neighbors on means to reduce border costs and appropriate the benefits of greater integration are high; Europeans know that well. Those demands are highest, and least easily met, in the poorest regions.

\footnotetext{
${ }^{45}$ That marginal increase in influence would in itself be healthy, and consistent with the view that large emerging market economies are under-represented in the multilateral banks (and the IMF), given their increased share of the world economy.
} 


\section{Bibliography}

African Development Bank, African Development Fund. 2000. "Economic Cooperation and Regional Integration Policy.” African Development Bank, African Development Fund. Washington, DC.

African Development Bank. 2003. Annual Report. Statistical Appendix.

African Development Bank Group. 2002. “Strategic Plan 2003-2007.” African Development Bank Group.

Agarwala, Ramgopal and Prakash, Brahm. 2002. "Regional Cooperation in Asia: LongTerm Progress, Recent Retrogression, and the Way Forward.” Asian Development Bank. Manila, Philippines.

Anand, P. B. 2002. "Financing the Provision of Global Public Goods.” WIDER Discussion Paper No. 2002/110. World Institute for Development Economics Research.

Anderson, James E. and van Wincoop, Eric. 2001. “Borders, Trade and Welfare." National Bureau of Economic Research Working Paper 8515. Cambridge, MA.

Asian Development Bank. 2002. “Asian Development Bank: Annual Report 2001 Highlights.” Asian Development Bank. Manila, Philippines.

Birdsall, Nancy and Liliana Rojas-Suarez, eds. 2004. Financing Development. The Power of Regionalism. Center for Global Development. Washington, DC.

Birdsall, Nancy. 1996. "Public Spending on Higher Education in Developing Countries: Too Much or Too Little?" Economics of Education Review, Vol. 15, No. 4.

Clemens, Michael. 2004. “The Long Walk to School: International education goals in historical perspective.” CDG Working Paper 37. Center for Global Development. Washington, DC.

Clemens, Michael, Charles Kenny, and Todd Moss. 2004. "The Trouble with the MDGs: Confronting Expectations of Aid and Development Success.” CGD Working Paper 40. Center for Global Development. Washington, DC.

EBRD. 2002. Annual Report. Annual Review and Financial Report. European Bank for Reconstruction and Development. London.

Gallup, John Luke and Sachs, Jeffrey, with Mellinger, Andrew D. 1999. “Geography and Economic Development.” Harvard Institute for International Development. 
Global Coalition for Africa, Economic Committee. 2001. "Regional Integration in SubSaharan Africa, Toward Rationalization and Greater Effectiveness." Global Coalition for Africa. Pretoria, South Africa.

Helliwell, John F. 1997. “National Borders, Trade and Migration.” National Bureau of Economic Research Working Paper 6027. Cambridge, MA.

International Development Association. 2002. “Additions to IDA Resources: Thirteenth Replenishment. Supporting Poverty Reduction Strategies.” http://siteresources.worldbank.org/IDA/Resources/IDA13Report.pdf

Inter-American Development Bank. 2003. “Inter-American Development Bank, Annual Report, Part I: The Bank in 2002.” The Inter-American Development Bank. Washington, DC.

International Monetary Fund. 2003. Direction of Trade Statistics. IMF. Washington, DC.

Kanbur, Ravi. 2001. “Cross-Border Externalities, International Public Goods and their Implications for Aid Agencies.” Working Paper. Cornell University. Ithaca.

Kanbur, Ravi, Todd Sandler and Kevin Morrison. 1999. “The Future of Development Assistance: Common Pools and International Public Goods.” ODC Policy Essay No. 25. Overseas Development Council. Washington, DC.

Kaul, Inge, Pedro Conceicao, Katell Le Goulven and Ronald Mendoza, (Eds.). 2003. "Providing Global Public Goods: Managing Globalization.” United Nations Development Programme. New York.

Kaul, Inge, Isabelle Grunberg and Marc A. Stern (Eds.). 1999. Global Public Goods. International Cooperation in the $21^{\text {st }}$ Century. Oxford University Press. New York.

McCallum, John. 1995. “National Borders Matter: Canada-U.S. Regional Trade Patterns.” American Economic Review, 85 (June): 615-23.

OECD. 2004. Development Assistance Committee-Creditor Reporting System. Organisation for Economic Co-operation and Development. Paris. http://www.oecd.org/dataoecd/50/17/5037721.htm

Radelet, Steven. 2002. “Challenging Foreign Aid.” The Center for Global Development, Washington, DC.

Radelet, Steven and Sachs, Jeffrey. 1998. “Shipping Costs, Manufactured Exports, and Economic Growth,” Earth Institute, Columbia University. New York, NY. 
Reisen, Helmut, Marcelo Soto, and Thomas Weithöner. 2004. “Financing Global and Regional Public Goods through ODA: Analysis and Evidence from the OECD Creditor Reporting System.” OECD Working Paper No. 232. Organisation for Economic Co-operation and Development. Paris.

Spolaore, Enrico and Wacziarg, Romain. 2002. “Borders and Growth.” Research Paper Series, Stanford Graduate School of Business.

United Nations Development Program. 2003. “Human Development Report.” Oxford University Press. New York.

United Nations. 2002. “Annual Report of the Administrator for 2001, Including the Results-Oriented Annual Report (ROAR). Statistical Annex. Executive Board of the United Nations Development Programme and of the United Nations Population Fund.” DP/2002/15/Add.2. United Nations. New York.

UNECA. 2004. Assessing Regional Integration in Africa. ECA Policy Research Report. United Nations Economic Commission for Africa. New York.

UNCTAD. 2004. Development and Globalization: Facts and Figures. United Nations Conference on Trade and Development. New York.

USITC. 2003. U.S. Trade and Investment with Sub-Saharan Africa. Fourth Annual Report. United States International Trade Commission. Washington, DC.

Wei, Shang-Jin. 1996. “Intra-National Versus International Trade: How Stubborn are Nations in Global Integration.” National Bureau of Economic Research Working Paper 5531. Cambridge, MA.

World Bank. 2004. World Development Report 2004. Making Services Work for Poor People. The World Bank. Washington, DC.

World Bank. 2004. Strategic Framework for Assistance to Africa. IDA and the Emerging Partnership Model. The World Bank. Washington, DC.

World Bank. 2004. World Development Indicators Database.

World Bank. 2003. "Memorandum of the President of the International Development Association to the Executive Directors on a Regional Integration Assistance Strategy for Central Africa.” Report No. 25328. The World Bank. Washington, DC.

World Bank. 2002. Annual Report. Volume 2. Financial Statements and Appendixes. World Bank. Washington, DC. 
World Bank. 2001. "Memorandum of the President of the International Development Association to the Executive Directors on a Regional Integration Assistance Strategy for West Africa." Report No. 22520-AFR. The World Bank. Washington, DC.

World Health Organization. 1999. "Proposed Programme Budget for 2000-2001. Implementation of Resolution EB103.R6. Report by the Secretariat.” WHO. Geneva.

World Trade Organization. 2002. International Trade Statistics. WTO. Geneva.

Yeats, Alexander J. 1998. "What Can Be Expected From African Regional Trade Arrangements? Some Empirical Evidence." The World Bank, International Trade Division. Washington, DC 


\section{Table 1}

Regional Public Goods Commitments by All Donors as a Share of Total ODA Commitments to All Developing Countries

$$
1997
$$

(percent)

(percent)

OECD CRS (broad sectoral set) ${ }^{1}$

OECD CRS (strict sectoral set) ${ }^{2}$

Bottom-up estimate ${ }^{3}$

$\mathrm{n} / \mathrm{a}$

3.4

Notes:

1. The broad sectoral definition of regional public goods includes health policy \& admin. management; medical education/training; health personnel development; medical services; health education; health personnel development; population \& reproductive health; water resources policy/admin. management;

education/training for water supply \& sanitation; water resources protection; water supply \& sanitation-large systems; River development; waste

management/disposal; post-conflict peace-building (UN); demobilization; land mine clearance; reconstruction relief; road transport; rail transport; transport policy

\& admin. management; water transport; storage; education/training in transport \& storage; communications policy \& admin. management; telecommunications; radio/television/print media; plant/post-harvest protection \& pest control; flood prevention/control; environmental education/training; rural development; aid to refugees (in recipient country); support to local and regional NGOs.

2. The strict regional public goods definition includes water resources protection; river development; rail transport; air transport; protection and pest control; flood prevention/control; and support to local/regional NGOs.

3. The bottom -up estimate is the sum of donor financing to the soft windows of the Inter-American Development Bank, The African Development Bank and the Asian Development Bank plus donor commitments to regional programs and projects for selected donors (see Table 1).

Source: Author's estimates using data from the OECD Creditor Reporting System (2004); Reisen et al. (2004). 
Table 2

Donor Commitments to Regional Programs and Projects for Selected Multilateral and Bilateral Donors (millions of US\$; percent)

\section{Regional Public Goods Commitments by Each Donor}

Regional Public Goods Commitments as Share of Total Commitments by Each Donor

2002 (millions of US\$) (percent)

World Bank ${ }^{6}$

African Development Bank

$\mathrm{n} / \mathrm{a}$

30

$\mathrm{n} / \mathrm{a}$

Inter-American Development Bank ${ }^{5}$

Asian Development Bank ${ }^{4}$

98
1.2

0.4

\section{1}

Total

788

Notes:

To the extent possible, commitments shown are for programs and projects that were managed by a regional organization such as the West African Monetary Union or the Central American Development Bank, regardless of the source. Commitments are from sources where they are probably shown in nominal terms.

1. The UNDP figure is for 2001 . The UNDP also granted an additional $\$ 9.5$ million for inter-regional and global projects that year, and $\$ 16$ million total for inter-country programs in 2000.

2. The WHO figure is for 1998-1999. The same amount was spent in 1996-1997.

3. These figures are probably inflated since they are figures for all "unspecified funds" going to a region, and are likely to include funds that in fact went to individual countries.

4. The Asian Development Bank's regional commitments reflect one project only, the Trade Finance Facilitation Program.

5. The Inter-American Development Bank also reports regional disbursements in addition to regional commitments. In 2002 , regional disbursements were $\$ 67$ million. In the past,

IDB has also made concessional loans to the Central American Bank for Economic Integration and to other subregional development banks.

6. The annual reports of the Inter-American Development Bank (Table IV. Yearly and Cumulative Loans and Guarantees), The African Development Bank (Annex II-7 Bank Group Loan and Grant Approvals by Country), the European Bank for Reconstruction and Development (Projects signed in 2002 section), and the Asian Development Bank (Public and Private Sector Loan Approvals by Country) all include a line item showing annual commitments to regional programs and projects. The World Bank Annual Report does not seem to provide a comparable line item.

7. This is the capital of six private equity or debt funds established to invest in or lend to private firms across two or more countries; whether these funds should be counted as multicountry programs as defined in this essay, is not entirely clear.

Sources: IDB Annual Reports; WB Annual Reports; African Development Bank Annual Reports; European Bank for Reconstruction and Development Annual Reports; Asian Development Bank Annual Reports; UNDP (2002); WHO Program Budget; USAID Green Book Online, http://qesdb.cdie.org/gbk/index.html; DFID online, http://www.dfid.gov.uk/sid2003/. 
Table 3

Gross Domestic Product (billions of US\$)

Country/Region

GDP in 2001

Netherlands

380.1

Ohio, USA

373.7

Chicago

348.6

Sub-Saharan Africa

318.1

Russian Federation

309.9

Hong Kong

161.9

South Africa

114.2

Egypt

98.4

Peru

54

Nigeria

41.3

Sudan

12.5

Note: Sub-Saharan Africa as defined by the World Bank, includes South Africa.

Sources: Ohio, USA and Chicago - US Bureau of Economic Analysis; others - World Bank, WDI 2003. 
Table 4

Trade and Developing Regions in 2001

\begin{tabular}{lcc} 
Region & $\begin{array}{c}\text { Regional trade } \\
\text { (as \% of all trade) }\end{array}$ & $\begin{array}{c}\text { Primary product exports } \\
\text { (as \% of merchandise exports) }\end{array}$ \\
\hline Africa & 7.8 & 71.7 \\
Latin America & 17.0 & 39.6 \\
Asia & 48.2 & 14.3 \\
\hline
\end{tabular}

Source: Author's calculations based on WTO (2002) International Trade Statistics, primary product exports from table IV.5; regional trade from Table III.3. 


\section{APPENDIX Table 1}

Global Public Goods ODA commitments as a Share of Total ODA Commitments (annual averages, percent)

\begin{tabular}{|c|c|c|c|c|c|c|}
\hline & \multicolumn{2}{|c|}{ 1990-1994 } & \multicolumn{2}{|c|}{ 1995-1998 } & \multicolumn{2}{|c|}{1999} \\
\hline & low income countries & $\begin{array}{c}\text { middle income } \\
\text { countries }\end{array}$ & low income countries & $\begin{array}{c}\text { middle income } \\
\text { countries }\end{array}$ & low income countries & $\begin{array}{c}\text { middle income } \\
\text { countries }\end{array}$ \\
\hline \multirow[t]{2}{*}{ World Bank (2001) } & 9.0 & 5.0 & 11.5 & 7.0 & 12.0 & 11.0 \\
\hline & $1990-1992$ & & 1996-1998 & & & \\
\hline $\begin{array}{l}\text { te Velde et al. } \\
(2002)\end{array}$ & 6.8 & & 8.8 & & & \\
\hline \multicolumn{7}{|c|}{ 1996-1997 } \\
\hline $\begin{array}{l}\text { Reisen et al. } \\
(2004)\end{array}$ & & & 16.0 & & & \\
\hline
\end{tabular}

Notes:

1. The definitions of global public goods vary across studies. See Anand (2002) for more details.

Sources: World Bank (2001b); Reisen et al. 2004; and te Velde et al. (2002) cited in Anand (2002) 


\section{APPENDIX Table 2}

\section{Selected World Bank Regional Programs and Projects in Africa}

African Regional Capacity

Building Network for

HIVIAIDS Prevention,

Treatment and Care

Project

Regional Trade Facilitation

Project (RTFP)

The Nile Basin Initiative

Multicountry

Demobilization and

Reintegration Program

(MDRP)

The Multicountry AIDS

Program for Africa (MAP)

BEAC Regional Payment

System Project

Southern African Power Market
In September 2004 IDA committed \$10 million to the African Regional Capacity Building Network for HIVIAIDS Prevention, Treatment and Care Project with a loan to the Government of Tanzania. ${ }^{1}$ The objective of the African Regional Capacity Building Network for HIVIAIDS Prevention, Treatment and Care Project is to increase access to comprehensive healthcare, improve HIVIAIDS prevention and treatment programs, and to sustain a network of subregional "learning sites" in order to increase training of healthcare practitioners in Kenya, Ethiopia, and Tanzania.

The Regional Trade Facilitation Project aims to alleviate poverty through private sector led growth by improving access to financing for productive transactions, and cross-border trade. The RTFP will support the establishment of a regional political insurance facility to be managed by a multilateral agency, the African Trade Insurance Agency (ATI). The operating and capital costs of the new agency will be shared by the participating countries, Burundi; Kenya; Malawi; Rwanda; Tanzania; Uganda; and Zambia, and a credit of $\$ 5$ million from the IDA will cover the costs of the initial period of $\mathrm{ATI}^{2}{ }^{2}$ The borrower is the African Trade Insurance Agency.

The Nile Basin Initiative is a regional partnership among 10 countries, Burundi; Democratic Republic of Congo; Egypt; Eritrea; Ethiopia; Kenya; Rwanda; Sudan; Tanzania; and Uganda launched in 1999 to coordinate management of the Nile River basin.

The MDRP provides a framework for disarmament, demobilization and reintegration in the Great Lakes Region and includes nine countries, Angola; Burundi; Central African Republic; Congo, Democratic Republic of Congo; Namibia; Rwanda; Uganda; and Zimbabwe. The estimated total cost of the program is $\$ 500$ million of which $\$ 350$ million will be donor grants and $\$ 150$ million IDA resources.

The overall objective of the MAP project is to combat the spread of HIVIAIDS in Africa. During the first stage of MAP the World Bank committed $\$ 500$ million to 14 African countries over little more than a year. During the second stage of MAP the program was replenished with another $\$ 500$ million, and MAPs have been approved in a total of 24 countries.

In 2002, IDA committed \$14.5 million to the BEAC Regional Payment System Project for Central Africa that is meant to improve the efficiency and security of the payment system in the Central African Economic and Monetary Union. The participating countries are Cameroon; Central African Republic; Chad; Congo; Equatorial Guinea and Gabon.

The Southern African Power Market Project for Zambia aims to facilitate the development of an efficient regional power market. The project has four component, it will support the Southern African Power Pool Coordination Center (SAPP); increase the capacity of the transmission corridor from the Democratic Republic of Congo (DRC) to the SAPP; enable the pooling of power resources; and the Project Preparation and Management - Financing of the project will be coordinated by the World Bank, with co-financing expected from bilateral donors (USAID, NORAD). The program has been prepared with the financial support of a grant from Japan of US $\$ 618,000$ and the recipient of this grant was the Government of Zimbabwe who passed it on to the SAPP Coordination Center. IDA made a commitment of $\$ 179$ million in 2003 and the borrowers are multiple governments.

\footnotetext{
Notes:

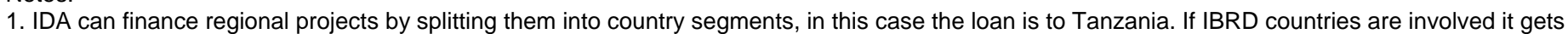
harder since if there is a non-performing country this country cannot borrow.

2. These are the initial countries that may be extended to cover all of Africa.
}

Sources: World Bank (2004) Strategic Framework for Assistance to Africa; World Bank Project Database,

http://web.worldbank.org/WBSITE/EXTERNAL/PROJECTS/0,,menuPK:235787 pagePK:64020917 piPK:64021009 theSitePK:40941,00.htmI 